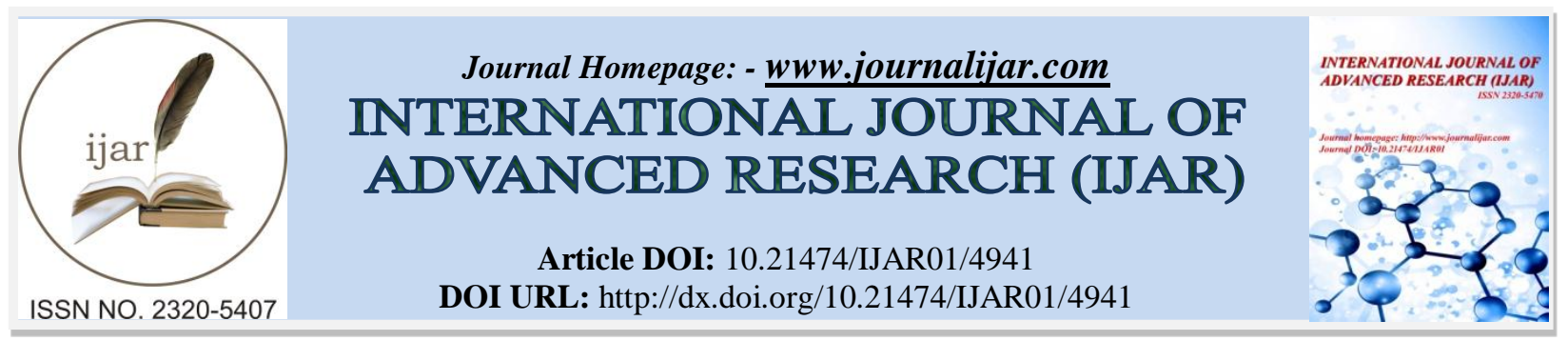

RESEARCH ARTICLE

\title{
A REVIEW: SCOPE OF UTILIZING SEAWEED AS A BIOFERTILIZER IN AGRICULTURE.
}

Rinku V. Patel ${ }^{1,2}$, Krishna Y. Pandya ${ }^{1,2}$, Dr. R.T. Jasrai ${ }^{3}$ and "Dr. Nayana Brahmbhatt ${ }^{2}$.

1. Sophisticated Instrumentation Centre for Applied Research and Testing, Vallabh Vidyanagar-388120, Gujarat,India.

2. Department of Biology, V.P. \& R.P.T.P. Science College, Sardar Patel University, Vallabh vidyanagar-388120, Gujarat, India.

3. Department of Chemistry, R.K. Parikh Arts \& Science College, Sardar Patel University, Petlad- 388450, Gujarat, India.

\section{Manuscript Info}

Manuscript History

Received: 24 May 2017

Final Accepted: 26 June 2017

Published: July 2017

Key words:-

Biofertilizer, seaweed, bio-diversity, nutrient content, micro- macro elements

\section{Abstract}

Biofertilizers offer a new eco-friendly technology which would overcome short comings of the conventional chemical based farming. Biofertilizers showed positive influence on both soil sustainability and plant growth. Biofertilizers are not only the alternative to chemical fertilizers but also tend to increase the soil fertility and plant productivity which discuss in present review study. Seaweed plays an important and vital role in the marine ecosystem and growing in large amount in the sea. Seaweed can be regarded as a potential source of bio-fertilizer in of dried or fresh form; it helps to enhance biochemical constituents like carbohydrates, lipids, proteins, fibers, ash, phenol, dietary fiber etc in plant. The seaweed also good source of micro \& macro elements required for plant nutrition. Seaweed extract is effective for improves the quality of produce and soil conditioner. This technology can be implemented in form of organic farming for sustainable agriculture which is better solution for eco friendly approach.

Copy Right, IJAR, 2017,. All rights reserved.

\section{Introduction:-}

All plants need certain minerals nutrients to survive in environment. These minerals occur naturally in the soil and are taken up from the soil by the roots of the plants. Most soil usually has enough of these minerals to keep plants healthy. However, plants are gradually absorbed some nutrients or nutrients are washed out of the soil, and need to be replaced to maintain optimal growth and development of the plants. Most common mineral nutrients that need replacing are N, P, K. Fertilizers are manufactured by mixtures of products that contain N, P, K and other necessary nutrients. The fertilizers are necessary to add in the soil because the nutrients in the soil get used up due to repeated cultivation of the plant. The crop yield also starts decreasing so, in order of revive the fertility of the soil, fertilizers are necessary. Fertilizers are divided in two types: (1) Chemical fertilizers and (2) Organic fertilizers.

The excessive uses of chemical fertilizers (man - made or synthetic composition) in agriculture are costly with adverse effects on physico-chemical properties of soils, plant, animal and human life. Chemical fertilizers are more resistant in the environment which in some cases is harmful to the environment- especially, on soil fertility and are actually causing huge amount of soil and land degradation (Liu et al., 2009) because most of the microorganism 
decrease following the use of chemical fertilizers in increasing level (Katsunori, 2003). The ground water contamination is the biggest issues faced during the use chemical fertilizers. In the soil nitrogen fertilizers breaks down and converts into nitrates which are water soluble and travels easily through the soil and they can remain in that position for decades and these accumulation is causing the problem. These accumulations of chemicals lead to water pollution both surface and ground water.

Organic fertilizers are derived from natural products, which were once living organisms. Organic fertilizers are generally slow-acting because they have to decompose and to become plant nutrients; however, this also means their benefits are longer lasting. All natural nutrients to soil, increases soil organic matter, improves soil structure and improves water holding capacity, reduces soil crusting problems, reduces erosion from water and wind, slow and consistent release of nutrients.

\section{Biofertilizer:-}

The term of biofertilizer represent everything from manures to plant extracts. Biofertilizers consist of $\mathrm{N}$ fixers (Rhizobium, Azotobacter, blue green algae, Azolla), phosphate solubilizing bacteria (PSB) and fungi (mycorrhizae) which increase the supply or availability of macro (primary \& secondary nutrient) and/or micro nutrients (growth stimulus) to the target crop. Biofertilizers have shown great potential as a, renewable and environmental friendly source of plant nutrient. Biofertilizers are ready to use and used as a live formation of beneficial microorganisms, when it amended to seed, root or soil, it mobilizes the availability and utility of the microorganisms and thus the power to improve the soil health and genesis to support microbial growth and vegetation.

\section{Seaweed as a bio- fertilizer:-}

Seaweeds are one of the most important marine sources of the world. The seaweed extract is available as fertilizer in different forms such as SLF (Seaweed Liquid Fertilizers), LF (Liquid Fertilizers) and powder form of seaweed manure have been used as a biofertilizer. In market, seaweed extracts available for several years as fertilizer additives and beneficial results from their use have been reported (Booth, 1969).

The components of seaweed such as macro and micro- element nutrients, amino acids, vitamins, cytokinin, auxins, and abscisic acid (ABA)- like growth substances affect cellular metabolism in treated plants to enhance growth and crop yield. The use of natural seaweed as fertilizer has allowed for partial substitution of prevailing synthetic fertilizer. Some studies have reported a wide range of beneficial effects of seaweed extract applications (like soil drench, foliar spray, soil drench+foliar spray) on plants, such as improving moisture- (water holding capacity) and by promoting growth of beneficial soil microbes enhanced soil health, which are conditioning substances of secretion of soil and which are promote root growth and development, improve nutrient uptake by roots, promote rooting of cutting, early flowering and increase fruit set $\&$ yield, elicit abiotic stress tolerance in plants, nematodes, enhance defense against pests and diseases, bacterial and fungal pathogens.

Nutrient content and Bio-chemical parameter of Different seaweeds:-

Table 1:- The comparison of different seaweeds macro- nutrient content review as per some references

\begin{tabular}{|c|c|c|c|c|c|}
\hline Name of seaweed & Type & $\mathrm{N} \mathrm{mg/g}$ & P mg/g & $\mathrm{K} \mathrm{mg/g}$ & Reference \\
\hline Sargassum wightii & B & 174.02 & 45.56 & 72.83 & K. Divya et al., 2015 \\
\hline Sargassum crassifolium & $\mathrm{B}$ & 0.4 & 0.009 & 1.520 & S. Sutharsan et al., 2014 \\
\hline Padina pavonica & $\mathrm{B}$ & 0.01090 & 0.00926 & 0.16013 & Chabani et al., 2013 \\
\hline Dictyota dichotoma & B & 175.02 & 44.56 & 71.84 & K. Sasikumar et al., 2011 \\
\hline Laurencia obtuse & $\mathrm{R}$ & 3.9 & 3.8 & 2 & \multirow[t]{3}{*}{ Safinaz and Ragaa et al., 2013} \\
\hline Corallina elongate & $\mathrm{R}$ & 3.4 & 3.8 & 1.6 & \\
\hline Jania rubens & $\mathrm{R}$ & 4 & 3.5 & 1.6 & \\
\hline Padina pavonica & B & 0.07985 & 0.00069 & 0.00278 & \multirow[t]{3}{*}{ Chabani et al., 2015} \\
\hline Ulva linza & $\mathrm{G}$ & 0.05716 & 0.00120 & 0.01265 & \\
\hline Ulva lactuca & $\mathrm{G}$ & 0.12609 & 0.00300 & 0.01634 & \\
\hline Ulva lactuca & $\mathrm{G}$ & 174.02 & 45.56 & 75.83 & K. Divya et al., 2015 \\
\hline
\end{tabular}

Whereas, $\mathrm{G}=$ Green Seaweed, B= Brown seaweed, $\mathrm{R}=$ Red Seaweed, N-Nitrogen content, P-Phosphorus content and K-Potassium content 
Table 2:- The comparison of different seaweed bio-chemical parameters review as per some references

\begin{tabular}{|c|c|c|c|c|c|c|c|c|}
\hline Name of seaweed & Type & P \% & $\mathrm{C} \%$ & Ph\% & $\mathbf{L \%}$ & F\% & A\% & References \\
\hline Chaetomorpha crassa & $\mathrm{G}$ & 25.48 & 26.94 & - & 1.50 & 34.29 & 26.94 & \multirow{9}{*}{$\begin{array}{l}\text { Pakawan } \\
\text { Setthamogkol et } \\
\text { al., } 2015\end{array}$} \\
\hline Chaetomorpha linum & G & 30.70 & 26.08 & - & 1.30 & 31.94 & 26.08 & \\
\hline Gracillaria tenuistipata & $\mathrm{R}$ & 26.13 & 41.45 & - & 0.75 & 12.21 & 41.45 & \\
\hline Gracillaria fisheri & $\mathrm{R}$ & 26.71 & 47.47 & - & 0.62 & 11.78 & 47.47 & \\
\hline Caulerpa racemosa & G & 23.42 & 48.10 & - & 0.67 & 6.68 & 48.10 & \\
\hline Caulerpa branchypus & $\mathrm{G}$ & 26.34 & 54.38 & - & 1.42 & 6.04 & 54.38 & \\
\hline Caulerpa lentilifera & $\mathrm{G}$ & 12.68 & 27.19 & - & 1.09 & 4.83 & 27.19 & \\
\hline Caulerpa taxifolia & G & 33.83 & 41.24 & - & 3.26 & 7.17 & 41.24 & \\
\hline Ulva rigida & $\mathrm{G}$ & 13.32 & 67.84 & - & 0.15 & 5.69 & 67.84 & \\
\hline $\begin{array}{l}\text { Monostroma latissimum } \\
\text { Wittrock }\end{array}$ & $\mathrm{G}$ & 0.14 & 0.6 & 0.071 & - & - & - & \multirow[t]{13}{*}{$\begin{array}{l}\text { Nirmal Kumar J. I } \\
\text { et al., } 2014\end{array}$} \\
\hline Cladophora sp. & $\mathrm{G}$ & 0.12 & 0.73 & 0.066 & - & - & - & \\
\hline Padina sp. & B & 1.84 & 0.62 & 0.380 & - & - & - & \\
\hline D.acrostichoides & $\mathrm{B}$ & 0.04 & 0.7 & 0.21 & - & - & - & \\
\hline Sargassum tenerimum & $\mathrm{B}$ & 0.4 & 0.4 & 0.36 & - & - & - & \\
\hline $\begin{array}{lll}\text { Sargassum cinctum } \mathrm{J} . \\
\text { Agardh }\end{array}$ & $\mathrm{B}$ & 0.13 & 0.63 & 0.26 & - & - & - & \\
\hline Sargassum cinerrum & $\mathrm{B}$ & 0.13 & 0.63 & 0.277 & - & - & - & \\
\hline Caulerpa indica & $\mathrm{B}$ & 0.14 & 0.92 & 0.27 & - & - & - & \\
\hline Caulerpa trinoids & $\mathrm{B}$ & 0.08 & 0.29 & 0.12 & - & - & - & \\
\hline $\begin{array}{ll}\text { Dictyota } & \text { dichotoma } \\
\text { Lamouroax } & \end{array}$ & $\mathrm{B}$ & 0.08 & 0.39 & 0.088 & - & - & - & \\
\hline T. ornate & $\mathrm{B}$ & 0.05 & 0.57 & 0.18 & - & - & - & \\
\hline $\begin{array}{l}\text { Gracillaria corticata J. } \\
\text { Agardh }\end{array}$ & $\mathrm{R}$ & 0.19 & 0.225 & 0.96 & - & - & - & \\
\hline $\begin{array}{l}\text { Gracillaria } \\
\text { micropterum }\end{array}$ & $\mathrm{R}$ & 0.09 & 0.29 & 0.1 & - & - & - & \\
\hline Ulva lactuca & $\mathrm{G}$ & 20.12 & 44.81 & - & 4.09 & - & 22.08 & \multirow{3}{*}{$\begin{array}{l}\text { H. M. Khairy and } \\
\text { S. M. El. Shafay, } \\
2013\end{array}$} \\
\hline Jania rubens & $\mathrm{R}$ & 12.93 & 42.18 & - & 2.39 & - & 39.25 & \\
\hline P. capillaceae & B & 23.72 & 50.49 & - & 2.71 & - & 13.02 & \\
\hline $\begin{array}{l}\text { Enteromorpha } \\
\text { intestinalis }\end{array}$ & $\mathrm{G}$ & 16.2 & 24 & - & 1.4 & - & - & \multirow{12}{*}{$\begin{array}{lr}\text { K. Manivannan } \\
\text { and } \\
\text { Thirumaran, } 2008\end{array}$} \\
\hline Enteromorpha clathrata & $\mathrm{G}$ & 11 & 23 & - & 4.5 & - & - & \\
\hline Ulva lactuca & $\mathrm{G}$ & 3 & 23 & - & 1.5 & - & - & \\
\hline Codium tomentosum & $\mathrm{G}$ & 6 & 20 & - & 2.5 & - & - & \\
\hline Padina gymnospora & $\mathrm{B}$ & 17 & 21 & - & 1.2 & - & - & \\
\hline Colpomenia sinuosa & $\mathrm{B}$ & 10.5 & 22 & - & 2.3 & - & - & \\
\hline Sargassum tenerimum & $\mathrm{B}$ & 12.0 & 24 & - & 1.2 & - & - & \\
\hline Sargassum wightii & $\mathrm{B}$ & 11 & 23.5 & - & 2.2 & - & - & \\
\hline Turbinaria conoides & $\mathrm{B}$ & & 24 & - & 2.0 & - & - & \\
\hline Gracilaria folifera & $\mathrm{B}$ & 6 & 22.5 & - & 3.0 & - & - & \\
\hline Hypnea valentiae & $\mathrm{B}$ & 8 & 24 & - & 1.4 & - & - & \\
\hline Acanthophora spififera & $\mathrm{B}$ & 11.8 & 24 & - & 1.5 & - & - & \\
\hline Ulva faciata & G & 14.98 & 39.86 & 5.987 & 0.21 & - & - & \multirow{6}{*}{$\begin{array}{l}\text { P. Anantharaman } \\
\text { et al., } 2014\end{array}$} \\
\hline $\begin{array}{l}\text { Chaetomorpha } \\
\text { antennina }\end{array}$ & $\mathrm{G}$ & 13.45 & 34.96 & 6.342 & 0.34 & - & - & \\
\hline Spyridia hypnoides & $\mathrm{R}$ & 12.87 & 47.09 & 8.94 & 0.42 & - & - & \\
\hline Amphiroa anceps & $\mathrm{R}$ & 7.86 & 25.76 & 4.456 & 0.21 & - & - & \\
\hline Sargassum wightii & $\mathrm{B}$ & 16.34 & 54.09 & 16.482 & 0.51 & - & - & \\
\hline Chnoospora maxima & $\mathrm{B}$ & 9.87 & 55.86 & 19.351 & 0.54 & - & - & \\
\hline Caulerpa racemosa & $\mathrm{G}$ & 18.3 & 83.2 & 14.3 & 19.1 & - & - & \multirow{2}{*}{$\begin{array}{l}\text { Rameshkumar S. } \\
\text { et al., } 2013\end{array}$} \\
\hline Ulva faciata & G & 14.7 & 70.1 & 18.1 & 0.5 & - & - & \\
\hline
\end{tabular}




\begin{tabular}{|l|l|l|l|l|l|l|l|l|}
\hline Chnoospora minima & $\mathrm{B}$ & 11.3 & 28.5 & 19.7 & 0.9 & - & - & \\
\hline Padina gymnospora & $\mathrm{B}$ & 10.5 & 38.3 & 32.3 & 11.4 & - & - & \\
\hline Acanthopora spicefera & $\mathrm{R}$ & 18.9 & 65.6 & 34.7 & 2.1 & - & - & 20.25 \\
\hline Laurencia obtusa & $\mathrm{R}$ & $\begin{array}{l}142.9 \\
4\end{array}$ & 199.69 & 0.529 & - & - & $\begin{array}{l}\text { Funda } \\
\text { al., } 2015\end{array}$ \\
\hline Laurencia papillosa & $\mathrm{R}$ & 23.63 & 155.23 & 0.246 & - & - & 23.33 \\
\hline Jania rubens & $\mathrm{R}$ & 13.82 & 374.02 & 0.053 & - & - & 26.50 \\
\hline Codium fragile & $\mathrm{G}$ & 25.49 & 643.93 & 0.095 & - & - & 21.79 \\
\hline Ulva lactuca & $\mathrm{G}$ & 56.76 & 506.69 & 0.221 & - & - & 12.37 & \\
\hline Amphiroa fragilissima & $\mathrm{R}$ & 7.31 & 18.77 & - & - & 3.52 & - & $\begin{array}{l}\text { Narasimman, } \\
\text { and } \\
\text { Murugaiyan, } 2013\end{array}$ \\
\hline
\end{tabular}

Whereas, $\mathrm{P}=$ Protein content, $\mathrm{C}=$ Carbohydrate content, $\mathrm{L}=$ Lipid content, $\mathrm{F}=\mathrm{Fiber}$ content, $\mathrm{A}=\mathrm{Ash}$ content, $\mathrm{Ph}=$ Phenol content, TDF= Total Dietary Fiber, G= Green Seaweed, B= Brown seaweed, R= Red Seaweed

Table 3:- The comparison of micro and macro element of different seaweeds as per some references

\begin{tabular}{|c|c|c|c|c|c|c|c|c|}
\hline Name of seaweed & Type & $\begin{array}{l}\text { Fe mg/ } \\
100 \mathrm{~g}\end{array}$ & $\begin{array}{l}\mathbf{Z n} \\
\mathrm{mg} / \\
100 \mathrm{~g}\end{array}$ & $\begin{array}{l}\mathrm{Cu} \\
\mathrm{mg} / \\
100 \mathrm{~g}\end{array}$ & $\begin{array}{l}\mathbf{M g} \\
\mathrm{mg} / \\
100 \mathrm{~g}\end{array}$ & $\begin{array}{l}\mathbf{K} \\
\mathrm{mg} / \\
100 \mathrm{~g}\end{array}$ & $\begin{array}{l}\mathbf{N a} \\
\mathrm{mg} / \\
100 \mathrm{~g}\end{array}$ & References \\
\hline Caulerpa sp. & $\mathrm{G}$ & $\begin{array}{l}7.14 \pm \\
0.27\end{array}$ & $\begin{array}{l}3.41 \pm \\
0.35\end{array}$ & $<0.55$ & $\begin{array}{l}949 \pm \\
2.05\end{array}$ & $\begin{array}{l}4411 \pm \\
79.4\end{array}$ & $\begin{array}{l}7042 \pm \\
21.8\end{array}$ & \multirow[t]{7}{*}{$\begin{array}{l}\text { D. Krishnaiah et } \\
\text { al., } 2008\end{array}$} \\
\hline Ulva lactuca & $\mathrm{G}$ & $\begin{array}{l}4.65 \pm \\
0.41\end{array}$ & $\begin{array}{l}1.87 \pm \\
0.07\end{array}$ & $<0.55$ & $\begin{array}{l}560 \pm \\
4.85\end{array}$ & $\begin{array}{l}6026 \pm \\
22.2\end{array}$ & $\begin{array}{l}3901 \pm \\
71.6\end{array}$ & \\
\hline Sargassum sp. & $\mathrm{B}$ & $\begin{array}{l}6.83 \pm \\
0.07\end{array}$ & $\begin{array}{l}3.74 \pm \\
0.30\end{array}$ & $<0.55$ & $\begin{array}{l}953 \pm \\
2.52\end{array}$ & $\begin{array}{l}10040 \pm \\
32.1\end{array}$ & $\begin{array}{l}4024 \pm \\
25.1\end{array}$ & \\
\hline $\begin{array}{l}\text { Eucheuma } \\
\text { denticulate }\end{array}$ & $\mathrm{R}$ & $\begin{array}{l}6.45 \pm \\
0.07\end{array}$ & $\begin{array}{l}6.38 \pm \\
0.45\end{array}$ & $<0.55$ & $\begin{array}{l}725 \pm \\
3.70\end{array}$ & $\begin{array}{l}3636 \\
\pm 72.6\end{array}$ & $\begin{array}{l}4448 \pm \\
45.1\end{array}$ & \\
\hline Gracillaria sp. & $\mathrm{R}$ & $\begin{array}{l}3.65 \pm \\
0.26\end{array}$ & $\begin{array}{l}4.35 \pm \\
0.34\end{array}$ & $<0.55$ & $\begin{array}{l}565 \pm \\
3.51\end{array}$ & $\begin{array}{l}3417 \\
\pm 76.3\end{array}$ & $\begin{array}{l}5465 \pm \\
27.4\end{array}$ & \\
\hline Gelidiella acerosa & $\mathrm{R}$ & $\begin{array}{l}10.60 \pm \\
0.34\end{array}$ & $\begin{array}{l}5.25 \pm \\
0.21\end{array}$ & $<0.55$ & $\begin{array}{l}657 \pm \\
7.60\end{array}$ & $\begin{array}{l}30.34 \\
\pm 41.6\end{array}$ & $\begin{array}{l}3976 \pm \\
18.1\end{array}$ & \\
\hline $\begin{array}{l}\text { Kappaphycus } \\
\text { alvarezii }\end{array}$ & $\mathrm{R}$ & $\begin{array}{l}5.47 \pm \\
0.17 \\
\end{array}$ & $\begin{array}{l}5.09 \pm \\
0.14\end{array}$ & $<0.55$ & $\begin{array}{l}639 \pm \\
2.90\end{array}$ & $\begin{array}{l}3877 \\
\pm 25.1 \\
\end{array}$ & $\begin{array}{l}3944 \pm \\
52.0\end{array}$ & \\
\hline $\begin{array}{l}\text { Stoehospermum } \\
\text { marginatum }\end{array}$ & $\mathrm{B}$ & 0.50 & 1.58 & 3.014 & 17.31 & 0.107 & 5.77 & $\begin{array}{l}\text { S. Sivasangari } \\
\text { Ramya } \text { et } \text { al., } 2015\end{array}$ \\
\hline $\begin{array}{l}\text { Cladophora } \\
\text { glomerata }\end{array}$ & $\mathrm{G}$ & 27 & 0.57 & 0.9 & 60 & - & - & \multirow[t]{9}{*}{$\begin{array}{l}\text { P. Anatharaman et } \\
\text { al., } 2010\end{array}$} \\
\hline Ulva reticulata & $\mathrm{G}$ & 28 & 0.64 & 1.62 & 180 & - & - & \\
\hline $\begin{array}{l}\text { Halimeda } \\
\text { macroloba }\end{array}$ & $\mathrm{G}$ & 59 & 0.72 & 1.42 & 115 & - & - & \\
\hline Halimeda tuna & G & 18.5 & 0.48 & 1.0 & 32 & - & - & \\
\hline Dictyota dichotoma & $\mathrm{B}$ & 20 & 0.47 & 0.85 & 105 & - & - & \\
\hline Padina pavonica & $\mathrm{B}$ & 34 & 0.64 & 1.38 & 80 & - & - & \\
\hline Gracillaria crassa & $\mathrm{R}$ & 24 & 0.57 & 1.0 & 80 & - & - & \\
\hline Gelidiella acerosa & $\mathrm{R}$ & 28 & 0.43 & 0.8 & 54 & - & - & \\
\hline $\begin{array}{l}\text { Hypnea } \\
\text { musciformis }\end{array}$ & $\mathrm{R}$ & 40 & 0.53 & 0.095 & 86 & - & - & \\
\hline Ulva pertusa & $\mathrm{G}$ & - & $\begin{array}{l}0.8 \pm \\
0.2\end{array}$ & $\begin{array}{l}1.0 \pm \\
8.3\end{array}$ & $\begin{array}{l}3670 \pm \\
533\end{array}$ & $\begin{array}{l}1224.1 \pm \\
349.2\end{array}$ & $\begin{array}{l}376.7 \\
\pm 63.3\end{array}$ & \multirow{2}{*}{ 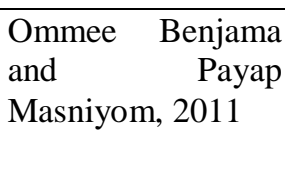 } \\
\hline Ulva intestinalis & $\mathrm{G}$ & - & $\begin{array}{l}1.5 \pm \\
0.2\end{array}$ & $\begin{array}{l}0.9 \pm \\
0.3\end{array}$ & $\begin{array}{l}3098 \pm 1 \\
157.2\end{array}$ & $\begin{array}{r}2538.6 \\
\pm 320.3\end{array}$ & $\begin{array}{l}1064.5 \\
\pm 489.1 \\
\end{array}$ & \\
\hline
\end{tabular}

Whereas, $\mathrm{G}=$ Green Seaweed, $\mathrm{B}=$ Brown seaweed, $\mathrm{R}=$ Red Seaweed 


\section{Review of literature:-}

Role of seaweed extract on seed germination, plant growth and yield:-

The treatment of seaweed extract increased the seed germination, seedling growth and yield of crop. Nerissa Ali $e t$ al. (2016) observed the effect on grown under tropical field conditions with an alkaline seaweed extract made from Ascophyllum nodosum (ASWE) on tomato plants (Lycopersicum esculentum Mill). In this study, two field experiments and one greenhouse experiment were conducted to evaluate methods of application, dosage, the impact of each on plant growth parameters, the quality and yield of fruit. The higher concentration of ASWE resulted in a significant increase in plant height (37\%) and plant fruit yield (63\%) compared to control plants.

Rosalba Mireya Hernández-Herrera et al. (2014) have experimented the effect of different concentration of (0.2, 0.4, and $1.0 \%$ ) liquid seaweed extracts (LSEs) made from two green seaweed viz. Ulva lactuca, Caulerpa sertularioides and two brown seaweed viz. Padina gymnospora, and Sargassum liebmannii as biostimulants on the germination and growth of tomato (Solanum lycopersicum) under greenhouse and in laboratory conditions using two application of foliar spray and soil drench of LSEs. Ulva lactuca and Padina gymnospora at lower concentration (2\%) showed better germination. The better germination response in germination rate related with lower mean germination time, maximum germination index and germination energy, and accordingly greater plumule and radicle length and seedling vigour. Application of foliar spray was found to be less effective in plant height $(75 \mathrm{~cm})$ than the soil drench (up to $79 \mathrm{~cm}$ ).

Sivasangari Ramya et al. (2015) studied the effect on growth, biochemical and yield of brinjal by using liquid extracts of brown marine alga Stoechospermum marginatum. The different concentrations of liquid extracts were prepared and applied as foliar spray on the brinjal seedlings, raised in pots experimental with maintained under natural conditions. Their results revealed that the number of fruits and fruit weight were increased at lower concentration only $(1.5 \%)$. In contrast, liquid extracts at high concentration $(5 \%)$ was found to have inhibitory effect on brinjal plants as compared to the control sprayed with water.

Sutharsan et al., (2014) were experimented the effect of foliar application of Sargasssum crassifolium extract at different concentration (concentration $(10 \%, 20 \%, 50 \%$ and 100\%) to apply on tomato plants at five times from 3 weeks after transplanting and the results was recorded after two weeks. At $20 \%$ of root dry weight $(81.57 \%)$, shoot dry weight $(80.92 \%)$, fruit number $(57.87 \%)$ and fruit yield per hectare $(58.70 \%)$, along with fruit total acidity $(76.95 \%)$ and total soluble solids content $(25.71 \%)$ of fruit significantly increased as compare to control, while all mentioned parameters reduced at $100 \%$ of foliar application. Therefore, it concluded $20 \%$ concentration of seaweed extract an be used to enhance the growth.

Safinaz and Ragaa, (2013) observed the effect of three species of red marine algae (Laurencia obtusa, Corallina elongata and Jania rubens) and it's mixture to use as biofertilizer to enhance growth of Maize (Zea mays L.) plants. The results indicated that the application of Laurencia obtusa + Jania rubens caused $48.21 \%$ increase in plant length, $61.84 \%$ increase in potassium content and increase in number of leaves.

Emmanuel et al., (2015) were determined the impact of seaweed liquid extract (SLE) of Laurencia pinnatifida, Surgassum duplicatum and Caulerpa scalpelliformis on seed germination and growth of the legume crop of Vigna mungo. The effect on growth parameters of different concentrations $(5,10,20,40,60,80$ and $100 \%$; v/v) of SLE and the highest growth parameter was reported at $10 \%$ concentration.

Mounir et al., (2015) were experimented the effect of seaweed extract (SWE) from two macroalgae species such as Ulva rigida and Fucus spiralis on drought stress tolerance in green bean plants (Phaseolus vulgaris L.). In their study, examination of growth parameters and some physiological and biochemical parameters showed that SWE extract enhanced vegetative growth with and without under drought stress condition in bean plant. Maximum plant height and dry weight were observed with $25 \%$ of $U$. rigida and $F$. spiralis extract.

Fatma et al., (2014) were conducted the efficiency of using seaweeds (Padina vickersiae, Enteromorpha compressa, Ulva fasciata, Gelidium crinale, Jania rubens and Laurencia obtusa) as biofertilizers for improving growth and grain quality of maize (Zea maize L.) plants. Thus, using algae as biofertilizer improved growth, yield and grain quality of maize plants. 
Rao and Chatterjee (2014) were observed the effect of Seaweed Liquid Fertilizer (SLF) of Gracilaria textorii and Hypnea musciformis on seed germination, growth and yield parameters such as number of leaves, weight of fruits of selected plants such as Brinjal, Tomato and Chilly and result to be effective in increasing the growth and yield in low doses (1:4 and 1:6 conc.) than 1:2, higher concentrations and the control of Seaweed Liquid Fertilizer.

Rinku et al., (2017) were determined the effect of Gracilaria corticata J Ag., Kappaphycus alvarezii and mixture of both as a biopriming agents (different concentration of $1 \%, 2 \%, 3 \%, 4 \% \& 5 \%$ ), that alters the responses of brinjal and tomato vegetables seeds germination and better results was found at $4 \%$ concentration in all treatment.

Deviand and Mani (2015) conducted the different concentration of $(2.5 \%, 5.0 \%, 7.5 \%, 10 \%$ and $15 \%)$ of fertilizer of seaweed saps Kappaphycus alvarezii and Gracilaria sp. on growth, yield and quality of rice Var. ADT 43 and significantly higher growth, yield attributes and chlorophyll content were recorded at $15 \%$ Kappaphycus alvarezii sap with $100 \%$ RDF (Recommended Dose of Fertilizer) as compare to Gracilaria sp. sap with $100 \%$ RDF and the grain was increased in both seaweed fertilizer treatment as compare to control.

Chitra and Sreeja (2013) studied the effect of Caulerpa peltata and Gracillaria corticata liquid extracts on seed germination, growth and pigment content of green gram (Vigna radiata (L.). At low level of seaweed liquid fertilizer application was promoted the seed germination and Gracillaria corticata extract was better than Caulerpa peltataat $4 \%$ concentration of growth and pigment content.

Zodape et al., (2011) have determined the effect of Kappaphycus alvarezii sap (seaweed) with 5\% concentration by foliar spray on growth and yield of tomato in field during Kharif season of 2006-07. The result was reported to increase in number of fruits per plant, size of fruit and yield of tomato fruit $(60.89 \%)$ as compared to control.

El-Sheekh et al., (2000) were experimented the effect of three green seaweeds viz. Cladophora dalmatica, Enteromorpha intestinalis, Ulva lactucaand three red seaweeds viz. Corallina mediterranea, Jania rubens, and Pterocladia pinnata seaweed extracts on seed germination, seedling growth and some metabolic processes of 'Fabe beans' (Vicia faba L.). The crude extract from Cladophora dalmatica applied shows maximum increase in seed germination, length of main root and shoot system and number of lateral root at $60 \%$ treatment. Protein content in root and shoot systems, total soluble sugar and chlorophyll content of leaves increased in all crude extract of seaweed. The cytokinin content of red seaweed was lower than in green seaweed.

Zodape et al., (2008) found effect of different concentration of $(2.5 \%, 5.0 \%, 7.5 \%$ and $10.0 \%)$ to obtain from Kappaphycus alvarezii onyield and quality. In the result, significantly increased in length $(31.77 \%)$ and diameter $(18.26 \%)$ of fruit, number of fruits $(37.47 \%)$ and fruit yield $(20.47 \%)$ per net plot and nutritional quality of Okra(Abelmoschus esculentus L.) as compared to control.

Ayun Vinuba et al., (2008) were found the beneficial effects of liquid seaweed fertilizer (LSF) made from Gracilaria corticata on seedling growth and biochemical parameters of pulses and cereals. LSF at 20\% concentration increased the morphological parameters such as the lengths of shoot and root fresh and dry weight, the pigment of chlorophyll and protein contents Vigna mungo (black gram).

Rajasulochana et al., (2008) were found the effect of Ulva lactuca extract on the growth of Brassica juncea Hook. F, Phaseolus mungo L. and Thomas and Trigonella foenum graceum L. In this experiment, positive response showed in Phaseolus mungo and to promote over all seedling growth of the three test plants. The application of extract was found to promote over all seedling growth of the three test plants.

Thirumaran et al., (2009) were experimented the effect of seaweed liquid fertilizer (SLF) of Rosenvigea intricate alone or mixing with synthetic NPK chemical fertilizer on seedling growth parameters, pigment contents, yield and soil characters of 'Ladies finger' [Abelmoschus esculentus (L) Medikus].Before sowing, the seeds of selected plant were soaked in SLF of different concentrations (10 to 100\%) for $12 \mathrm{hrs}$. The result shows that SLF of low concentration $20 \%$ promoted seedling growth, fruit yield and pigment contents and at higher concentrations of SLF was noted minimum improvement in growth parameters.

Dogra and Mandradia (2012) was determined the effects of soil applications of different concentrations of seaweed extract from Ascophyllum nodosum on growth, yield and downy mildew severity of onion during the Rabi season of 
2009. The seaweed granules were applied as the basal dose $\left(1.5,2.0,2.5,3.0 \& 3.5 \mathrm{~g} / \mathrm{m}^{2}\right)$. The highest yield recorded was with application of $2.5 \mathrm{~g} / \mathrm{m}^{2}$ followed by $3.0 \mathrm{~g} / \mathrm{m}^{2}$ that resulted in 120.8 per cent and 102.5 per cent respectively compared to control.

Sridhar and Rengasamy (2002) were experimented the effect of seaweed liquid fertilizer derived from the green seaweed Ulva lactuca to check its effect on physical \& biochemical parameters and yield of Capsicum annum (Chilly). The seaweed extract was resulted to improve maximum growth and yield at $1.0 \%$ concentration of SLF.

\section{Conclusion:-}

As per the above review studied seaweeds can be utilized as an excellent source of macro \& micro nutrients, fibers, ash, phenol, carbohydrates and higher content of plant growth hormones. Growth promoting substances released by biofertilizers improve plant's physiological \& biochemical parameters. In addition to these advantages, biofertilizers are commercially promising too. They are also comparatively cheaper than the chemical fertilizers.

\section{Acknowledgement:-}

The authors are thankful to principal of our college Dr. B. D. Patel Sir for their thorough support \& guidance.

\section{References:-}

1. Anantharaman P., Karthikaidevi G., Manivannan K., Thirumaran G. and Balasubramanian T. (2010): Mineral Composition of Marine Macroalgae from Mandapam Coastal Regions; Southeast Coast of India Recent Research in Science and Technology, 2(10): 66-71.

2. Anantharaman P., Saranya C., Parthiban C. (2014): Evaluation of antibacterial and antioxidant activities of seaweeds from Pondicherry coast. Adv in App Sci Res, 5(4): 82-90.

3. Asma Chbani, Hiba Mawlawi and Laurence Zaouk (2013): Evaluation of brown seaweed (Padina pavonica) as biostimulants of plant growth and development. Afri J of Agri Res, 8(13): 1155-1165. DOI: 10.5897/AJAR12.1346

4. Asma Chbani, Sandy Majed, Hiba Mawlawi (2015): Mineral Content of Mediterranean Seaweeds, Padina pavonica L. (Pheophytae, Ulva lactuca L. and Ulva linza L. (Chlorophytae) for biofertilizing use. Inter J of Horti Sci and Tech, 2 (2): 133-140.

5. Ayun Vinuba, Pinky VR and Prakash JW (2008): Effects of seaweed extract on growth and biochemical parameters of black gram. Plant Archives, 8(1): 211-214.

6. Bhavanath, J., Reddy, C R K., Thakur, M C., and Rao, U M. (2009): Seaweeds of India: The diversity and distribution of seaweeds of the Gujarat coast. Developments in Applied Phycology, Springer, Dordrecht, 3(XII): 216.

7. Booth, E. (1969): The manufacture and properties of liquid seaweed extracts. Proc. Int. Seaweed Symp, 6: 622655.

8. Chitra G. and Sreeja P. S. (2013): A Comparative Study on the effect of Seaweed Liquid Fertilizers on the growth and yield of Vigna radiata (L.). Nat Env and Poll Tech, 12 (2): 359-362.

9. Devi N. L. and ManiS. (2015): Effect of seaweed saps Kappaphycus alvarezii and Gracilaria on Growth, Yield and Quality of Rice. Ind J of Sci and Tech, 8(19): 47610, ISSN (Print): 0974-6846.

10. Dhargalkar V. K. \& Deshmukhe G. V. (1996): Subtidal marine algae of the Dwaraka Coast (Gujarat). Ind J of Mari Sci, 25: 297-301.

11. Divya K., Mary Roja N. and Padal S.B. (2015): Effect of seaweed liquid fertilizer of Sargassum wightii on germination, growth and productivity of brinjal. Inter J of Adv Res in Sci, Engi and Tech, 2(10): 868871.www.ijarset.com

12. Divya K., Mary Roja N. and Padal S.B. (2015): Influence of seaweed liquid fertilizer of Ulva lactuca on the seed germination, growth, productivity of Abelmoschus esculentus (L.). Inter J of Pharma Res, 5(12): 344-346 www.ssjournals.com, DOI: 10.7439/ijpr.

13. Dogra B.S. and Rakesh K Mandradia (2012): Effect of seaweed extract on growth and yield of onion. Inter J of Farm Sci, 2(1): 59-64.

14. Duduka Krishnaiah, Rosalam Sarbatly, D. M. R. Prasad and Awang Bono (2008): Mineral content of some seaweeds from Sabah's south china sea. Asi J of Sci Res, 1:166-170. DOI:10.3923/ajsr.2008.166.170

15. El-Sheekh M. M. and El-Saied AEDF (2000): Effect of crude seaweed extracts on seed germination, seedling growth and some metabolic processes of Vicia faba L. Cytobios, 101(396): 23-35. 
16. Emmanuel Joshua Jebasingh S., Lakshmikandan M., Vasanthakumar P., Sivaraman K. (2015): Improved Seedling Growth and Seed Germination in Legume Crop Vigna mungo (L.) Hepper Utilizing Marine Macro Algal Extracts. Proceedings of the National Academy of Sciences, India Section B: Biological Sciences, 85(2): 643-651.

17. Fatma M. Ai-Shakankery, Ragaa A. Hamonda and Ammar M.M. (2014): The promotive effect of different concentrations of marine algae as biofertilizers on growth and yield of maize (Zea mays L.) plants. J of che, bio and phy Sci, Sec. B., 4(4): 3201-3211.

18. Funda Turan, Senem Ozgun, Selin Sayın, Gul Ozyılmaz (2015): Biochemical composition of some red and green seaweeds from Iskenderun Bay, the northeastern Mediterranean coast of Turkey. J. Black Sea/Mediterranean Environment, 21(3): 239-249.

19. Isaiah Nirmal Kumar, Megha Barot, Rita Kumar (2014): Phytochemical analysis and antifungal activity of selected seaweeds from Okha coast, Gujarat. Ind J of Coa Life Medi, 2(7): 535-540 doi:10.12980/JCLM.2.201414J26.

20. Katsunori, S. (2003): Sustainable and environmentally sound land use in rural areas with special attention to land degradation: APFED.

21. Khairy H.M., El-Shafay S.M. (2013): Seasonal variations in the biochemical composition of some common seaweed species from the coast of Abu Qir Bay, Alexandria, Egypt. Oceanologia 55(2): 435-452.

22. Krishnamurthy, V. and Joshi H.V. (1970): A checklist of Indian marine algae. Central salt and Marine chemicals Research Institute, Bhavnagar, pp.39.

23. Liu Yu, Zhang Jun-biao, Jiang DU. (2009): Factors Affecting Reduction of Fertilizer Application by Farmers: Empirical Study with Data from Jianghan Plain in Hubei Province.

24. Manivannan, K., Thirumaran, G., Karthikai Devi, G., Hemalatha, A. and Anantharaman, P. (2008): Biochemical Composition of Seaweeds from Mandapam Coastal Regions along Southeast Coast of India. AmeEur J of Bot, 1: 32-37.

25. Megha Barot, Nirmal Kumar J. I., Rita N. Kumar (2015): Seaweed Species Diversity in Relation to Hydro Chemical Characters of Okha Coast, Western India. Int J of Rec Res and Re, 8 (3): 16-28.

26. Mounir Mansori, Halima Chernane, Salma Latique, Abdelali Benaliat, Driss Hsissou, Mimoun El Kaoua (2015): Seaweed extract effect on water deficit and antioxidative mechanisms in bean plants (Phaseolus vulgaris L.). J of App Phy, 27(4): 1689-1698.

27. Narasimman, S and Murugaiyan K. (2013): Biochemical and Mineral contents of selected Green Seaweeds from Gulf of Mannar Coastal region, Tamilnadu, India. Int J of Res in plant sci, 3(4): 96-100, ISSN 2249-9717. http://www.urpjournals.com.

28. Nerissa Ali, Aidan Farrell, Adesh Ramsubhag, Jayaraj Jayaraman (2016): The effect of Ascophyllum nodosum extract on the growth, yield and fruit quality of tomato grown under tropical conditions. J of App Phy, 28: 13531362. DOI 10.1007/s10811-015-0608-3.

29. Ommee Benjama and Payap Masniyom (2011): Nutritional composition and physiochemical properties of two green seaweeds (Ulva pertusa and U. intestinalis) from the Pattani Bay in Southern Thailand Songklanak. J. Sci. Tech, 33(5): 575-583. http://www.sjst.psu.ac.in.

30. Pakawan Setthamongkol, Suriyan Tunkijjanukij, Kriengkrai Satapornvanit and Jintana Salaenoi (2015): Growth and Nutrients Analysis in Marine Macroalgae Kasetsart J. Nat. Sci, 49: 211-218.

31. Rajasulochana, N., Josmin Laali Nisha L.L. and Leelavathy. A. (2008): Effect of Ulva lactuca extract on the growth of Phaseolus mungo L., Brassica juncea Hook. F. and Thomas and Trigonella foenum graceum L. Ind Hydro, 11(2): 275279.

32. Rameshkumar, S., Ramakritinan, C. M., and Yokeshbabu, M. (2013): Proximate composition of some selected seaweeds from Palk bay and Gulf of Mannar, Tamilnadu, India. Asi J of Biome and Pharma Sci, 3(16): 1-5.

33. Rao G. M. N. and Chatterjee R. (2014): "Effect of Seaweed Liquid Fertilizer from Gracilaria textorii and Hypnea musciformis on Seed Germination and Productivity of Some Vegetable Crops". Uni J of Plant Sci, 2(7): 115-120, http://www.hrpub.org

34. Rinku V. Patel, Krishna Y. Pandya, R.T. Jasrai and Nayana Brahmbhatt (2017): Effect of hydropriming and biopriming on seed germination of Brinjal and Tomato seed. Res. J. Agriculture and Forestry Sci. 5(6): 1-14.

35. Rosalba Mireya Hernández-Herrera, Fernando Santacruz-Ruvalcaba, Mario Alberto Ruiz-López, Jeffrey Norrie, Gustavo Hernández-Carmona (2014): Effect of liquid seaweed extracts on growth of tomato seedlings (Solanum lycopersicum L.). J of App Phy, 26(1): 619-628.

36. Safinaz, A. F. and Ragaa, A. H. (2013): "Effect of some red marine algae as biofertilizers on growth of maize (Zea mayz L.) plants”. Int Food Res J, 20(4): 1629-1632. 
37. Sasikumar K, Govindan T, Anuradha C. (2011): Effect of seaweed liquid fertilizer of Dictyota dichotoma on growth and yield of Abelmoschus esculentus (L). Eur J Exp Biol 1: 223-227.

38. Sasikumar K., Govindan T. and Anuradha C. (2011): Effect of Seaweed Liquid Fertilizer of Dictyota dichotoma on growth and yield of Abelmoschus esculantus L. Eur J of Exp Bio, 1(3): 223-227, www.pelagiaresearchlibrary.com

39. Sivasangari Ramya S., Vijayanand N., Rathinavel S. (2015): Foliar application of liquid biofertilizer of brown alga Stoehospermum marginatum on growth, biochemical and yield of Solanum melongena. Int J of rec of org was in agri, 4(3): 167-173.

40. Sridhar, S. and R. Rengasamy (2002): Effect of Seaweed liquid fertilizer obtained from Ulva lactuca on the biomass, pigments and protein content of Spirulina platensis. Sea Res Utili, 24: 145-149.

41. Sutharsan S., Nishanthi S., and Srikrishnah S. (2014): "Effects of Foliar Application of Seaweed (Sargassum crassifolium) Liquid Extract on the Performance of Lycopersicon esculentum Mill. In Sandy Regosol of Batticaloa District Sri Lanka”. Ameri-Eur J. Agric. \& Env. Sci., 14(12): 1386-1396.

42. Thirumaran G., Arumugam M., Arumugam R., Anantharaman P. (2009): Effect of seaweed liquid fertilizer on growth and pigment concentration of Abelmoschus esculentus (I) Medikus. Am Euras J Agron, 2: 57-66.

43. Untawale, A.G., Dhargalkar V.K. and Agadi. V.V. (1983): A checklist of marine algae from India. National Institute of Oceanography, Goa. Tech. Rep. pp. 42.

44. Zodape S. T., Abha Gupta, Bhandari S. C., Rawat U. S., Chaudhary D. R., Eswaran K. and Chikara J. (2011): "Foliar application of seaweed sap as biostimulant for enhancement of yield and quality of tomato (Lycopersicon esculentum Mill.)". J of Sci \& Ind Res, 219: 215-219, http://www.academicjournals.org/AJAR.

45. Zodape S. T., Kawarkhe V. J., Patolia J. S., Warade A. D. (2008): Effect of liquid seaweed fertilizer on yield and quality of okra (Abelmoschus esculentus L.). J of Sci \& Ind Res, 67: 1115-1117. 